\title{
Catchability in Some of the Major Groundfish Fisheries off the East Coast of Canada
}

\author{
A. T. Pinhorn \\ Department of Fisheries and Oceans, Science Branch \\ Northwest Atlantic Fisheries Centre, P. O. Box 5667 \\ St. John's, Newfoundland, Canada A1C 5X1
}

\begin{abstract}
Catchability coefficients $(q)$ as derived from the relationship between indices of catch per unit of effort (CPUE) and average exploitable biomass were positively correlated with indices of technological changes in the fleets fishing for the major groundfish stocks off the east coast of Canada. There was no evidence of correlation of $q$ with abundance indices from research-vessel survey data. It was therefore concluded that the increase in q observed in the mid-1970s was a result of improved technology by the vessels involved. This was further substantiated by the relative change in the proportion of the total effort expended by the large vessels in the fleet over the period examined and the corresponding larger CPUE of these vessels relative to the remainder of the fleet.
\end{abstract}

\section{Introduction}

Relationships between time series of fishing mortalities and fishing effort have frequently been used by the International Commission for the Northwest Atlantic Fisheries (ICNAF) and the Northwest Atlantic Fisheries Organization (NAFO) in the past to estimate the fishing mortality in the final year of sequential population analyses when assessing the status of marine fish stocks and providing advice to fisheries managers (NAFO, 1980a). The commonly used relationship is assumed to be linear and is expressed as:

$$
F=q f
$$

where $F=$ instantaneous fishing mortality,

$f=$ total annual fishing effort expressed in some standard unit

and $\mathrm{q}=\mathrm{a}$ proportionality constant.

However, in recent years this relationship has been superseded within NAFO by the relationship between catch per unit of effort (CPUE) and exploitable biomass because, unless a large proportion of the effort is actually measured rather than merely calculated from the ratio of the catch to a standard CPUE, the relationship between $F$ and fishing effort can be fortuitous (Pinhorn, MS 1986). This relationship between CPUE and stock biomass is commonly expressed as:

$$
\text { CPUE }=q B
$$

where CPUE = catch per unit of effort expressed in some standard unit,

$B=$ exploitable biomass of fish and $\mathrm{q}=\mathrm{a}$ proportionality constant, referred to in this paper as catchability coefficient.

Because this relationship has been widely used within NAFO under the linear assumption, it is instructive to consider the validity of this assumption and to investigate temporal trends in catchability for some of the major stocks.

\section{Materials and Methods}

Data used in these analyses were derived from sequential population analyses performed at the time of the 1985 assessments of the various stocks within mandates of NAFO and the Canadian Atlantic Fisheries Scientific Advisory Committee (CAFSAC) (Table 1). Stocks in this paper are identified by the NAFO Division or combination of Divisions which they occupy (e.g. 3LNO American plaice is the American plaice occupying NAFO Divisions $3 \mathrm{~L}, 3 \mathrm{~N}$ and 30 ). Although the last year of input data in these sequential population analyses was 1984, biomass estimates for 1980 and preceding years only were used because the output values for the most recent years of sequential population analyses are heavily influenced by the input values of the last year, which can be subject to significant error (Pope, 1972). Average biomass figures used in the calculation of $q$ for each year $\left(\bar{B}_{t}\right)$ were derived for each stock according to the formula of Rivard (1982) as follows:

$$
\bar{B}_{t}=\sum_{i=n}^{m} N_{i, t}\left(\frac{1-e^{-Z_{i, t}}}{Z_{i, t}}\right) W_{i, t}
$$


where $n$ = first age-group included in the summation,

$\mathrm{m}=$ oldest age-group,

$\mathrm{i}$ = age-group,

$\mathrm{t}=$ year,

$Z=$ instantaneous total mortality,

$\mathrm{N}=$ number of fish in the population

and $W=$ average weight of an individual fish estimated from sampling data of the commercial fishery.

In the calculation of $q$ using these average biomass values, exploitable biomass was approximated by summing the biomass at a given age and older in each year. Except for American plaice in Div. 3LNO, the earliest age was defined as the first age at which the fishing mortality was generally within the range of $40-60 \%$ of the average fishing mortality in those age-groups fully recruited to the fishery (Table 2). A peculiarity of American plaice is that the fishing mortality continues to increase with age up to very old ages in the population
(Brodie, MS 1985a). In fact, in the $1971-80$ period, the age of full recruitment to the fishery ranged between 15 and 18 years and the average age at which fishing mortality was $60 \%$ of that in fully recruited age-groups was 15 years. Beyond this age less than $5 \%$ of the population remains and fish beyond age 15 represent about $5 \%$ of the catch numbers. Therefore, age 8 was chosen as more reasonable for the purpose of exploitable biomass calculations.

Annual CPUE figures used in the calculation of $q$ were taken from the various NAFO and CAFSAC Research Documents (Table 1) and, except for American plaice and yellowtail flounder, were derived using the multiplicative model (Gavaris, 1980). CPUE figures for American plaice (Brodie, MS 1985a) and yellowtail flounder (Brodie, MS 1985b) were derived directly from logbooks on Canadian vessels of 501-999 gross registered tonnage (GRT) fishing in Div. 3LN. Since a large proportion of the catch in the period was taken by Canadian vessels, these CPUE figures should be representative of the entire fishery and comparable to those derived from the multiplicative model for other stocks.

TABLE 1. Basic data used in the analyses of catchability coefficients in the major groundfish fisheries in the Canadian Atlantic area.

\begin{tabular}{|c|c|c|c|c|c|c|c|c|c|c|c|c|c|c|c|c|}
\hline \multirow[b]{2}{*}{ Year } & \multicolumn{4}{|c|}{ Cod $-2 J 3 K L$} & \multicolumn{4}{|c|}{ Cod $-3 \mathrm{NO}$} & \multicolumn{4}{|c|}{ Cod $-3 \mathrm{Ps}$} & \multicolumn{4}{|c|}{ Cod $-4 T-4 V n$} \\
\hline & $\begin{array}{l}\text { CPUE } \\
\text { index }\end{array}$ & $\begin{array}{c}\text { Age } \\
5+ \\
\text { biom. } \\
(000 \mathrm{t})\end{array}$ & $\begin{array}{c}q \\
\text { index } \\
\left(\times 10^{2}\right)\end{array}$ & $\begin{array}{c}\text { Age } \\
3+ \\
\text { survey } \\
\text { abund. } \\
\text { index } \\
\text { Div. 3L }\end{array}$ & $\begin{array}{l}\text { CPUE } \\
\text { index }\end{array}$ & $\begin{array}{c}\text { Age } \\
4+ \\
\text { biom. } \\
(000 t)\end{array}$ & $\begin{array}{c}q \\
\text { index } \\
\left(\times 10^{2}\right)\end{array}$ & $\begin{array}{c}\text { Age } \\
3+ \\
\text { survey } \\
\text { abund. } \\
\text { index } \\
\text { Div. 3N }\end{array}$ & $\begin{array}{l}\text { CPUE } \\
\text { index }\end{array}$ & $\begin{array}{c}\text { Age } \\
5+ \\
\text { biom. } \\
(000 \mathrm{t})\end{array}$ & $\begin{array}{c}q \\
\text { index } \\
\left(\times 10^{2}\right)\end{array}$ & $\begin{array}{l}\text { Age } \\
4+ \\
\text { survey } \\
\text { abund. } \\
\text { index }\end{array}$ & $\begin{array}{l}\text { CPUE } \\
\text { index }\end{array}$ & $\begin{array}{c}\text { Age } \\
4+ \\
\text { biom. } \\
(000 \mathrm{t})\end{array}$ & $\begin{array}{c}q \\
\text { index } \\
\left(x 10^{2}\right)\end{array}$ & $\begin{array}{c}\text { Age } \\
4+ \\
\text { survey } \\
\text { abund. } \\
\text { index } \\
\text { Div. 4T }\end{array}$ \\
\hline 1959 & & & & & .86 & 174 & .49 & & 1.09 & 156 & .70 & & & & & \\
\hline 1960 & & & & & .88 & 163 & .54 & & .95 & 178 & .53 & & .39 & 270 & .14 & \\
\hline 1961 & & & & & .90 & 145 & .62 & & 1.41 & 148 & .95 & & .23 & 301 & .08 & \\
\hline 1962 & 2.53 & 1917 & .13 & & .95 & 163 & .58 & & 1.13 & 130 & .87 & & .35 & 258 & .14 & \\
\hline 1963 & 2.65 & 1757 & .15 & & 1.50 & 201 & .75 & & 1.36 & 122 & 1.11 & & .32 & 201 & .16 & \\
\hline 1964 & 2.47 & 1619 & .15 & & 1.22 & 215 & .57 & & 1.23 & 115 & 1.07 & & .32 & 158 & .20 & \\
\hline 1965 & 2.12 & 1393 & .15 & & 1.27 & 219 & .58 & & 1.32 & 105 & 1.26 & & .36 & 148 & .24 & \\
\hline 1966. & 2.23 & 1367 & .16 & & 1.30 & 296 & .44 & & 1.48 & 99 & 1.50 & & .36 & 133 & .27 & \\
\hline $1967^{\circ}$ & 2.46 & 1420 & .17 & & 1.51 & 307 & .49 & & 1.24 & 98 & 1.27 & & .39 & 135 & .29 & \\
\hline 1968 & 2.34 & 1421 & .17 & & 1.05 & 251 & .42 & & 1.53 & 110 & 1.39 & & .51 & 159 & .32 & \\
\hline 1969 & 1.91 & 1167 & .16 & & 1.02 & 196 & .52 & & 1.51 & 125 & 1.21 & & .51 & 178 & .29 & \\
\hline 1970 & 1.65 & 1037 & .16 & & .99 & 218 & .45 & & 1.26 & 124 & 1.02 & & .45 & 179 & .25 & \\
\hline 1971 & 1.39 & 998 & .14 & 40.1 & .91 & 199 & .46 & 56.0 & 1.25 & 104 & 1.20 & & .39 & 160 & .24 & 51 \\
\hline 1972 & 1.23 & 963 & .13 & 25.3 & .85 & 170 & .50 & 32.7 & 1.00 & 82 & 1.22 & 9.9 & .43 & 133 & .33 & 54 \\
\hline 1973 & 1.22 & 865 & .14 & 26.5 & .52 & 144 & .36 & 9.8 & .87 & 77 & 1.13 & 5.4 & .37 & 103 & .36 & 41 \\
\hline 1974 & 1.36 & 605 & .23 & 23.5 & .64 & 87 & .74 & 7.1 & .68 & 60 & 1.13 & 9.1 & 30 & 93 & .32 & 36 \\
\hline 1975 & 1.42 & 348 & .41 & 15.8 & .64 & 48 & 1.33 & 11.2 & .69 & 40 & 1.73 & 7.6 & .29 & 86 & .34 & 37.5 \\
\hline 1976 & 1.16 & 202 & .57 & 36.5 & .83 & 38 & 2.18 & 3.6 & .68 & 37 & 1.84 & 12.4 & .31 & 74 & .42 & 35 \\
\hline 1977 & 0.68 & 248 & .27 & 19.1 & .86 & 42 & 2.05 & 29.7 & .64 & 52 & 1.23 & 7.5 & .47 & 121 & .39 & 49 \\
\hline 1978 & 0.79 & 356 & .22 & 20.8 & .90 & 72 & 1.25 & 24.5 & 1.14 & 58 & 1.97 & 8.0 & .47 & 169 & .28 & 57 \\
\hline 1979 & 1.21 & 539 & .22 & 33.0 & 1.19 & 81 & 1.47 & 4.6 & .91 & 80 & 1.14 & 24.8 & .63 & 230 & .27 & 187 \\
\hline \multirow[t]{3}{*}{1980} & 1.30 & 726 & .18 & 27.2 & .95 & 104 & .91 & 5.2 & .66 & 84 & .79 & 7.3 & .64 & 209 & .31 & 194 \\
\hline & \multicolumn{4}{|c|}{ Source: } & \multicolumn{4}{|c|}{ Source: } & \multicolumn{4}{|c|}{ Source: } & \multicolumn{4}{|c|}{ Source: } \\
\hline & \multicolumn{4}{|c|}{ Baird and Bishop (MS 1985) } & \multicolumn{4}{|c|}{$\begin{array}{l}\text { CPUE index and age } 4+\text { biomass } \\
\text { Bishop and Baird (MS 1985a) } \\
\text { Age } 3+\text { survey abundance index } \\
\text { Div. } 3 \mathrm{~N} \text { (Bishop, pers. comm.) }\end{array}$} & \multicolumn{4}{|c|}{ Bishop and Baird (MS 1985b). } & \multicolumn{4}{|c|}{$\begin{array}{l}\text { CPUE index - 1959-65, calculated } \\
\text { from data by Chouinard (1985, pers. } \\
\text { comm.); } 1966-80-\text { Chouinard and } \\
\text { Clay (MS 1985) } \\
\text { Age 4+ biomass - 1960-70 Maguire } \\
\text { et al. (MS 1983); - 1971-80 } \\
\text { Choulnard (pers. comm., 1986) }\end{array}$} \\
\hline
\end{tabular}


TABLE 1. (continued)

\begin{tabular}{|c|c|c|c|c|c|c|c|c|c|c|c|c|c|c|c|c|c|c|c|c|}
\hline \multirow[b]{2}{*}{ Year } & \multicolumn{4}{|c|}{ Cod -4 Vsw } & \multicolumn{4}{|c|}{ Haddock - 4VW } & \multicolumn{4}{|c|}{ Haddock $-4 X$} & \multicolumn{4}{|c|}{ American plaice $-3 \mathrm{LNO}$} & \multicolumn{4}{|c|}{ Yellowtail - 3LNO } \\
\hline & $\begin{array}{l}\text { CPUE } \\
\text { index }\end{array}$ & $\begin{array}{c}\text { Age } \\
3+ \\
\text { biom. } \\
(000 \mathrm{t})\end{array}$ & $\begin{array}{c}9 \\
\text { Index } \\
\left(\times 10^{-1}\right)\end{array}$ & $\begin{array}{c}\text { Age } \\
3+ \\
\text { survey } \\
\text { abund. } \\
\text { index }\end{array}$ & $\begin{array}{l}\text { CPUE } \\
\text { index }\end{array}$ & $\begin{array}{c}\text { Age } \\
4+ \\
\text { biom. } \\
(000 t)\end{array}$ & $\begin{array}{c}q \\
\text { Index } \\
\left(x 10^{2}\right)\end{array}$ & $\begin{array}{c}\text { Age } \\
3^{+} \\
\text {survey } \\
\text { abund. } \\
\text { index }\end{array}$ & $\begin{array}{l}\text { CPUE } \\
\text { index }\end{array}$ & $\begin{array}{c}\text { Age } \\
4+ \\
\text { biom. } \\
(000 t)\end{array}$ & $\begin{array}{c}\mathbf{q} \\
\text { index } \\
\left(\times 10^{2}\right)\end{array}$ & $\begin{array}{c}\text { Age } \\
2+ \\
\text { survey } \\
\text { abund. } \\
\text { index }\end{array}$ & $\begin{array}{l}\text { CPUE } \\
\text { index }\end{array}$ & $\begin{array}{c}\text { Age } \\
8+ \\
\text { biom. } \\
(000 t)\end{array}$ & $\begin{array}{c}q \\
\text { index } \\
\left(x \quad 10^{2}\right)\end{array}$ & $\begin{array}{c}\text { Age } \\
8+ \\
\text { survey } \\
\text { abund. } \\
\text { index }\end{array}$ & $\begin{array}{l}\text { CPUE } \\
\text { index }\end{array}$ & $\begin{array}{c}\text { Age } \\
6+ \\
\text { biom. } \\
(000 \mathrm{t})\end{array}$ & $\begin{array}{c}q \\
\text { index } \\
(x \quad 10)\end{array}$ & $\begin{array}{c}\text { Age } \\
4+ \\
\text { survey } \\
\text { abund. } \\
\text { index }\end{array}$ \\
\hline \multicolumn{21}{|l|}{1959} \\
\hline 1960 & & & & & & & & & & & & & 1.07 & 211 & .51 & & & & & \\
\hline 1961 & & & & & & & & & & & & & .94 & 221 & .43 & & & & & \\
\hline 1962 & & & & & & & & & & & & & .79 & 237 & .33 & & & & & \\
\hline 1963 & & & & & & & & & & & & & .91 & 259 & .35 & & & & & \\
\hline 1964 & & & & & & & & & & & & & .95 & 289 & .33 & & & & & \\
\hline 1965 & & & & & & & & & & & & & .91 & 302 & .30 & & & & & \\
\hline 1966 & & & & & & & & & & & & & .88 & 314 & .28 & & & & & \\
\hline 1967 & & & & & & & & & & & & & .82 & 295 & .28 & & & & & \\
\hline 1968 & & & & & .66 & 260 & .25 & & .64 & 83 & 0.77 & & .63 & 270 & .23 & & .71 & 26 & .27 & \\
\hline 1969 & & & & & .55 & 232 & .24 & & .61 & 57 & 1.07 & & .55 & 237 & .23 & & .61 & 40 & .15 & \\
\hline 1970 & 1848 & 172 & 1.07 & 21 & .43 & 202 & .21 & 6.8 & .55 & 43 & 1.28 & 16.5 & .52 & 197 & .26 & & .60 & 50 & .12 & \\
\hline 1971 & 1487 & 115 & 1.29 & 71 & .46 & 128 & .36 & 4.2 & .42 & 33 & 1.27 & 25.4 & .48 & 163 & .29 & 243 & .60 & 49 & .12 & 203 \\
\hline 1972 & 1274 & 116 & 1.10 & 58 & 31 & 79 & .39 & 3.0 & .37 & 27 & 1.37 & 8.3 & .48 & 139 & .35 & 183 & .61 & 34 & .18 & 184 \\
\hline 1973 & 1193 & 84 & 1.42 & 154 & .43 & 56 & .77 & 1.5 & .44 & 27 & 1.63 & 25.2 & .52 & 117 & .44 & - & .65 & 24 & .27 & 102 \\
\hline 1974 & 867 & 84 & 1.03 & 31 & .41 & 42 & .97 & 4.6 & .57 & 22 & 2.59 & 46.0 & .43 & 127 & .34 & 154 & .42 & 21 & .20 & 92 \\
\hline 1975 & 686 & 60 & 1.14 & 24 & .52 & 50 & 1.03 & 5.3 & .61 & 33 & 1.85 & 17.1 & .42 & 142 & .30 & 169 & .40 & 18 & .22 & 78 \\
\hline 1976 & 845 & 63 & 1.34 & 37 & .48 & 69 & .69 & 3.1 & .64 & 42 & 1.53 & 19.9 & .43 & 153 & .28 & 355 & .33 & 19 & .17 & 85 \\
\hline 1977 & 910 & 104 & 0.88 & 62 & .68 & 74 & .92 & 13.3 & .75 & 39 & 1.92 & 47.7 & .41 & 185 & .22 & 409 & .42 & 19 & .22 & 120 \\
\hline 1978 & 1245 & 151 & 0.82 & 80 & .81 & 129 & .63 & 23.1 & .97 & 50 & 1.94 & 22.6 & .46 & 190 & .24 & 295 & .50 & 22 & .23 & 87 \\
\hline 1979 & 1421 & 152 & 0.93 & 64 & .76 & 250 & .30 & 24.3 & .90 & 59 & 1.53 & 35.6 & .50 & 215 & .23 & 337 & .52 & 17 & .31 & 76 \\
\hline \multirow[t]{5}{*}{1980} & 1518 & 179 & 0.85 & 65 & 1.08 & 314 & .34 & 42.1 & .91 & 54 & 1.69 & 43.1 & .60 & 223 & .27 & 354 & .64 & 25 & .26 & 92 \\
\hline & \multicolumn{4}{|c|}{ Source: } & \multicolumn{4}{|c|}{ Source: } & \multicolumn{4}{|c|}{ Source: } & \multicolumn{4}{|c|}{ Source: } & \multicolumn{4}{|c|}{ Source: } \\
\hline & \multicolumn{4}{|c|}{$\begin{array}{l}\text { CPUE index - 1970-80, Sinclair } \\
\text { and Gavaris (MS 1985) }\end{array}$} & \multicolumn{4}{|c|}{$\begin{array}{l}\text { CPUE index Mahon et al. } \\
\text { (MS 1985) }\end{array}$} & \multicolumn{4}{|c|}{$\begin{array}{l}\text { CPUE index, O'Boyle et al. } \\
\text { (MS 1984) }\end{array}$} & \multicolumn{4}{|c|}{ Brodie (MS 1985a) } & \multicolumn{4}{|c|}{ Brodie (MS 1985b) } \\
\hline & \multicolumn{4}{|c|}{$\begin{array}{l}\text { Age } 3+\text { biomass, Sinclair and } \\
\text { Gavaris (MS 1985) }\end{array}$} & \multicolumn{4}{|c|}{$\begin{array}{l}\text { Age } 4+\text { biomass calculated from } \\
\text { Mahon et al. (MS 1985) }\end{array}$} & \multicolumn{4}{|c|}{$\begin{array}{l}\text { Age } 4+\text { biomass calculated from } \\
\text { O'Boyle et al. (MS 1984) }\end{array}$} & & & & & & & & \\
\hline & \multicolumn{4}{|c|}{$\begin{array}{l}\text { Age } 3+\text { survey abundance index, } \\
\text { Gavaris and Sinclair (MS 1985) }\end{array}$} & \multicolumn{4}{|c|}{$\begin{array}{l}\text { Age } 3+\text { survey abundance index } \\
\text { Mahon et al. (MS 1985) }\end{array}$} & \multicolumn{4}{|c|}{$\begin{array}{l}\text { Age 2+ survey abundance index } \\
\text { O'Boyle et al. (MS 1984) }\end{array}$} & & & & & & & & \\
\hline
\end{tabular}

TABLE 2. Rationale for selection of first age used in calculation of exploitable biomass from sequential population analyses.

\begin{tabular}{ccc}
\hline Stock & $\begin{array}{c}\text { First } \\
\text { age used } \\
(\mathrm{yrs})\end{array}$ & $\begin{array}{c}\text { Ratio of fishing mortality at first age to } \\
\text { average fishing mortality in fully } \\
\text { recruited age-groups }\end{array}$ \\
\hline Cod-2J3KL & 5 & .58 \\
-3NO & 4 & .63 \\
-3Ps & 5 & .64 \\
- 4T-4Vn & 4 & .36 \\
(Jan-Apr) & & .41 \\
-4VsW & 3 & .49 \\
Haddock-4VW & 4 & .56 \\
-4X & 4 & .41 \\
Yellowtail-3LNO & 6 & \\
\hline
\end{tabular}

Indices of abundance used in regressions of $q$ against abundance were taken from results of research vessel surveys as reported in the various NAFO and CAFSAC Research Documents (Table 1). Except for yellowtail flounder in Div. 3LNO, the earliest age used in the abundance index for each stock was that age at which the fish were fully recruited to the research gear. This fully recruited age was defined as that age at which the weighted average ratio of numbers per standard tow at age $i+1$ in year $t+1$ to abundance indices at age $i$ in year $t$ for the period used in the analyses was first less than unity (Table 3). It was assumed that any density dependent effects on catchability would involve changes in the entire population of fish rather than simply that exploitable by the commercial gear if one is considering competition for food, space, etc. There- fore, it was considered that the portion of the population recruited to the small mesh research gear would be the best measure available of the changes in the entire population. In the case of yellowtail flounder, the age of full recruitment to the research gear was 6 years whereas the last age at which significant commercial catches were taken was 9 years. Thus changes in the catches of age 6 and older fish by the research gear were not considered representative of the population as a whole but catches of age 4 and older fish were used in regressions with $\mathrm{q}$, this being the age at which significant catches of fish are first taken by the research trawl.

Brake horsepower (BHP) and GRT per vessel used in regressions with $q$ were derived from data on $B H P$ and GRT for each vessel over 50 GRT by country contained in the ICNAF/NAFO List of Fishing Vessels published every third year during the 1959-80 period (ICNAF, 1959; NAFO, 1980b). A vessel was included in the calculation if it fished at all in any of NAFO Subareas 2-4, but was excluded if it fished exclusively in NAFO Subareas $0,1,5$ or 6 (Fig. 1). For a given year, the BHP and GRT of all vessels fishing in NAFO Subareas 2-4 were summed and divided by the total number of vessels fishing in these areas. The average annual $q$ values used in these regressions were derived by scaling the $q$ values for each stock considered in this paper to its highest value in the series and averaging the $q$ values for all stocks to derive an overall $q$ value for Subareas 2-4. 
TABLE 3. Rationale for selection of first age used in calculation of abundance index from research vessel surveys.

\begin{tabular}{cccc}
\hline \hline Stock & $\begin{array}{c}\text { First } \\
\text { age used } \\
\text { (age } \mathrm{i} \text { ) }\end{array}$ & $\begin{array}{c}\text { Ratio of numbers per } \\
\text { standard tow at age } \mathrm{i} \text { in } \\
\text { year } \mathrm{t} \text { to numbers at } \\
\text { age } \mathrm{i}-1 \text { in year } \mathrm{t}-1\end{array}$ & $\begin{array}{c}\text { Ratio of numbers per } \\
\text { standard tow at age } \mathrm{i}+1 \text { in } \\
\text { year } \mathrm{t}+1 \text { to numbers at } \\
\text { age } \mathrm{i} \text { in year } \mathrm{t}\end{array}$ \\
\hline Cod-2J3KL & 3 & 3.01 & .92 \\
-3NO & 3 & 2.12 & .52 \\
-3Ps & 4 & 1.57 & .65 \\
-4T-4Vn (Jan-Apr) & 4 & 1.17 & .88 \\
-4VSW & 3 & 1.54 & .80 \\
Haddock-4VW & 3 & 1.26 & .94 \\
-4X & 2 & 2.17 & .82 \\
American plaice-3LNO & 8 & 1.13 & .81 \\
\hline
\end{tabular}

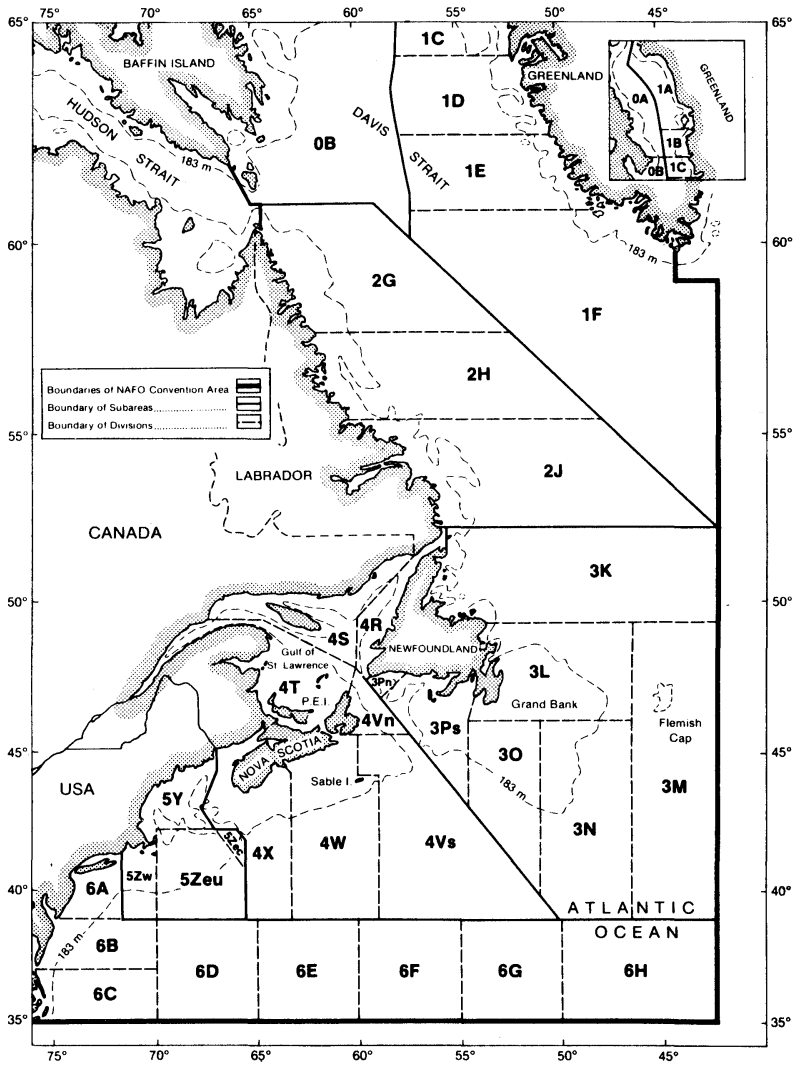

Fig. 1. Map of the NAFO Convention Area.

\section{Results}

A common feature for most of the stocks examined was an increase in q during the early 1970 s which reached a peak in the mid-1970s and declined thereafter (Fig. 2). This was also evident when q values for each stock were scaled to the highest value in its series and the resulting values averaged for each year over all stocks (Fig. 2). The latter showed a more or less stable situation during the 1960s with an increase which peaked in 1976 and declined thereafter.
The relationship between $q$ and abundance was investigated using results of stratified-random surveys to derive indices of abundance. The earliest year in which stratified-random surveys were conducted to provide abundance indices for stocks considered in this paper was 1970 for cod in Div. 4VsW and haddock in Div. 4VW and 4X, 1972 for cod in Subdiv. 3Ps and 1971 for all other stocks. Consequently, considering stocks individually, a maximum of 11 points was available for regressions of q versus research vessel abundance indices. Under these circumstances and given the inherent variability in research vessel indices (Byrne et al., 1981), individual anomalous points have a great influence on the significance of a regression. Therefore, to determine whether a relationship between $q$ and research vessel abundance indices existed overall, the q values and abundance indices for each stock were first scaled to the highest value in its series. These scaled $q$ values and abundance indices were then averaged over all stocks in each year to provide an overall $q$ index and abundance index for each year. These indicated a weak significant relationship between $q$ and abundance $(P=0.03)$ using the first age as shown in Table 1 for calculation of exploitable biomass and abundance indices. However, when one or two ages higher were used as the first age, the relationship was not significant indicating that this was probably a spurious relationship (Fig. 3).

With regards to the effect of technological changes, significant linear correlations were demonstrated between $q$ and BHP per vessel (Fig. 4A) and between q and GRT per vessel (Fig. 4B) for the 1959-80 period although the latter correlation was barely significant $(P=0.05)$. When the correlations were run with $q$ calculated from exploitable biomass using one or two ages higher, the correlations of q with GRT were not significant $(P=0.10$ and $P=0.25$ respectively) although those with $B H P$ were still significant $(P<0.005$ and $P=$ 0.015 respectively). At the same time, BHP per vessel was linearly correlated with GRT per vessel separately for 1959-74 and 1977-83 (Fig. 4C), the change coincid- 


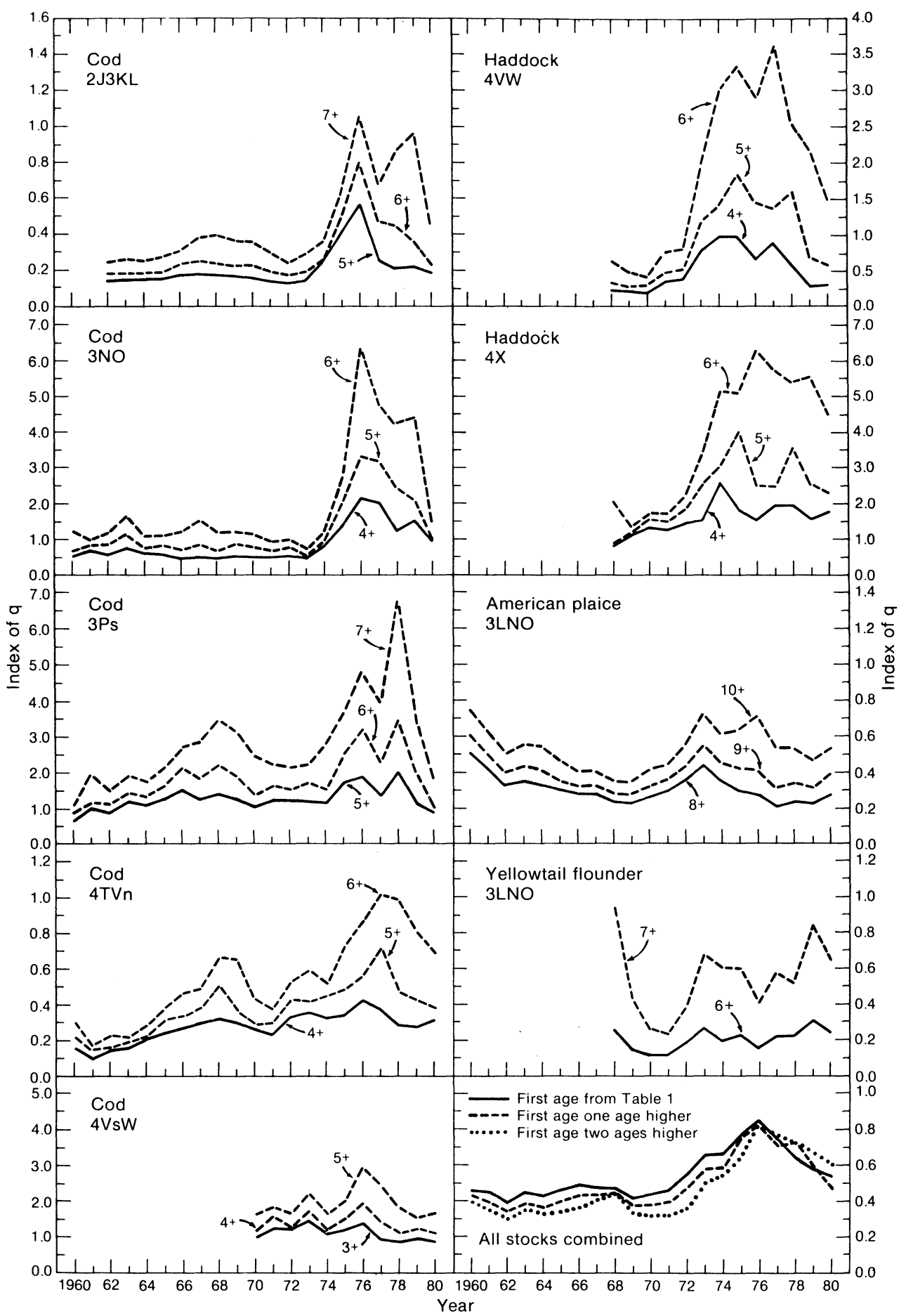

Fig. 2. Trends in catchability coefficient (q) for some of the major groundfish stocks in the Northwest Atlantic. Broken lines in the graph for each stock represent trends in q calculated from biomass estimates using as the first age for summation one age and two ages higher than that in Table 1.

ing with the Canadian Extension of Jurisdiction in 1977.

\section{Discussion and Conclusions}

Temporal changes in q values were evident for all stocks examined. These ranged from more or less ran- dom fluctuations (yellowtail) to distinct trends (cod Div. 2J3KL, 3NO and haddock Div. 4VW). A common feature for most stocks was an increase in $q$ in the mid-1970s. Using different first ages for calculation of exploitable biomass in deriving $q$ values accentuated this increase in the mid-1970s, thus indicating that it was not an artifact of the first age chosen (Fig. 2). 


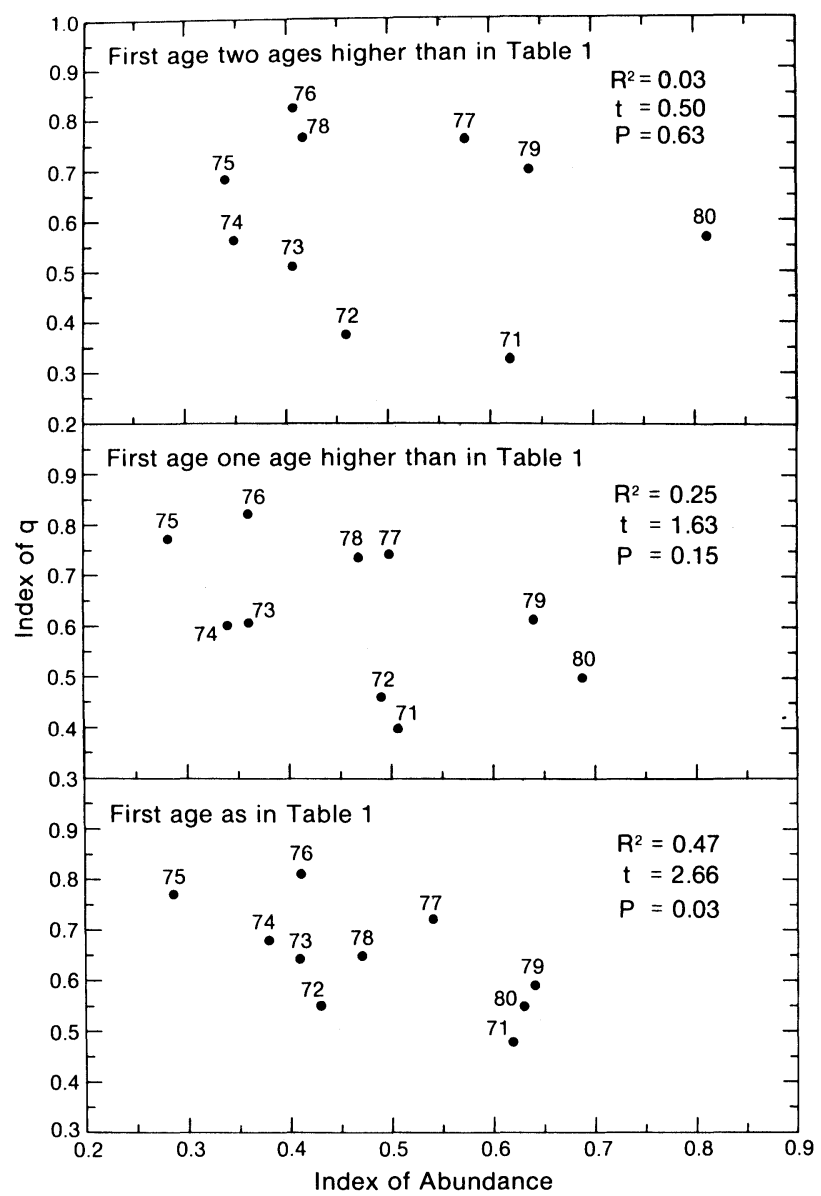

Fig. 3. Regressions of indices of catchability coefficient (q) and abundance combined over all stocks considered. See text for explanation of method of combining $q$ and abundance indices over stocks and significance of different first ages.

Gulland (1964) identified a number of factors contributing to such variations in $q$ with time, the major ones being changes in abundance of the fish being targetted and changes in fleet technology.

Changes in catchability coefficients and their relationship to stock abundance have been demonstrated for many pelagic fisheries. Winters and Wheeler (1985) reviewed literature on this subject and pointed out that $q$ has been shown to be inversely related to stock abundance. Studies are cited for herring stocks (Pope, 1980; Ulltang, 1980; Jakobsson, 1980; Anthony and Waring, 1980), as well as for other pelagic stocks including Atlantic menhaden (Brevoortia tyrannus) (Schaaf, 1980), Pacific sardine (Sardinops sagax caerula) (MacCall, 1976; Radovich, 1979), northern anchovy (Engraulis mordax) (Radovich, 1976), and Peruvian anchovy (Engraulis ringens) (Csirke, 1980). They also noted that published literature on changes in catchability coefficients for groundfish species and their response to changing abundance, is scanty. Houghton and Flatman (1980) demonstrated a significant inverse power relationship between catchability coefficient and stock biomass for North Sea cod but not between catchability coefficient and stock numbers. Pope and Garrod (1975) showed that for both Arcto-Norwegian and West Greenland cod, $q$ increased as stock size became smaller and concluded that this resulted from real changes in stock availability.

Changes in q with changes in stock abundance can be mediated in at least three ways; firstly, for species like cod and haddock, it is possible that at high levels of stock abundance a larger proportion of the stock is above the headline of the trawl, whereas below some level of abundance the fish are more apt to stay near the bottom. Below this abundance level, a larger proportion of the fish may be caught in each trawl haul resulting in a higher $q$ for the fleet as a whole.

Secondly, at lower levels of stock abundance, species may occupy a smaller area as suggested by Winters and Wheeler (1985) and thus a larger proportion of them may be caught by the gear. This would be particularly applicable again to species like cod and haddock, which tend to aggregate in particular areas at certain seasons (e.g. at spawning). The density of these aggregations may not decline as fast as the abundance of the stock as a whole, thus leading to higher values of $q$ at low stock sizes.

Thirdly, the area over which the fishing effort is deployed may decrease with decreasing stock size (i.e. fishing intensity may increase) so that a given CPUE will remove a larger proportion of the biomass at lower levels of stock abundance than at higher levels.

In the present study, changes in q were in general not correlated with changes in stock abundance.

Changes in vessel technology can also influence catchability of fish and can take the form of improved navigational and fish detection equipment, increased size of vessels and increased power. All of these factors can influence the amount of fish caught per unit of effort. These technological changes are poorly documented and no known detailed data base exists to analyze their effects. In the present analysis, GRT per vessel and BHP per vessel were used as indices of changes in technology. Increases in either or both of these would allow the vessel to tow a larger net, thus catching more fish per hour towing, resulting in increases in q. Significant correlations were in fact demonstrated between BHP and $q$ for all the groundfish fisheries studied in Subareas 2-4. Values of $q$ increased as the average BHP per vessel in the fleet increased from 1959 to 1974 with the advent of the large eastern and western European trawlers. Values of $q$ decreased after 1974 with the imposition of total allowable catch (TAC) regulations and more importantly 

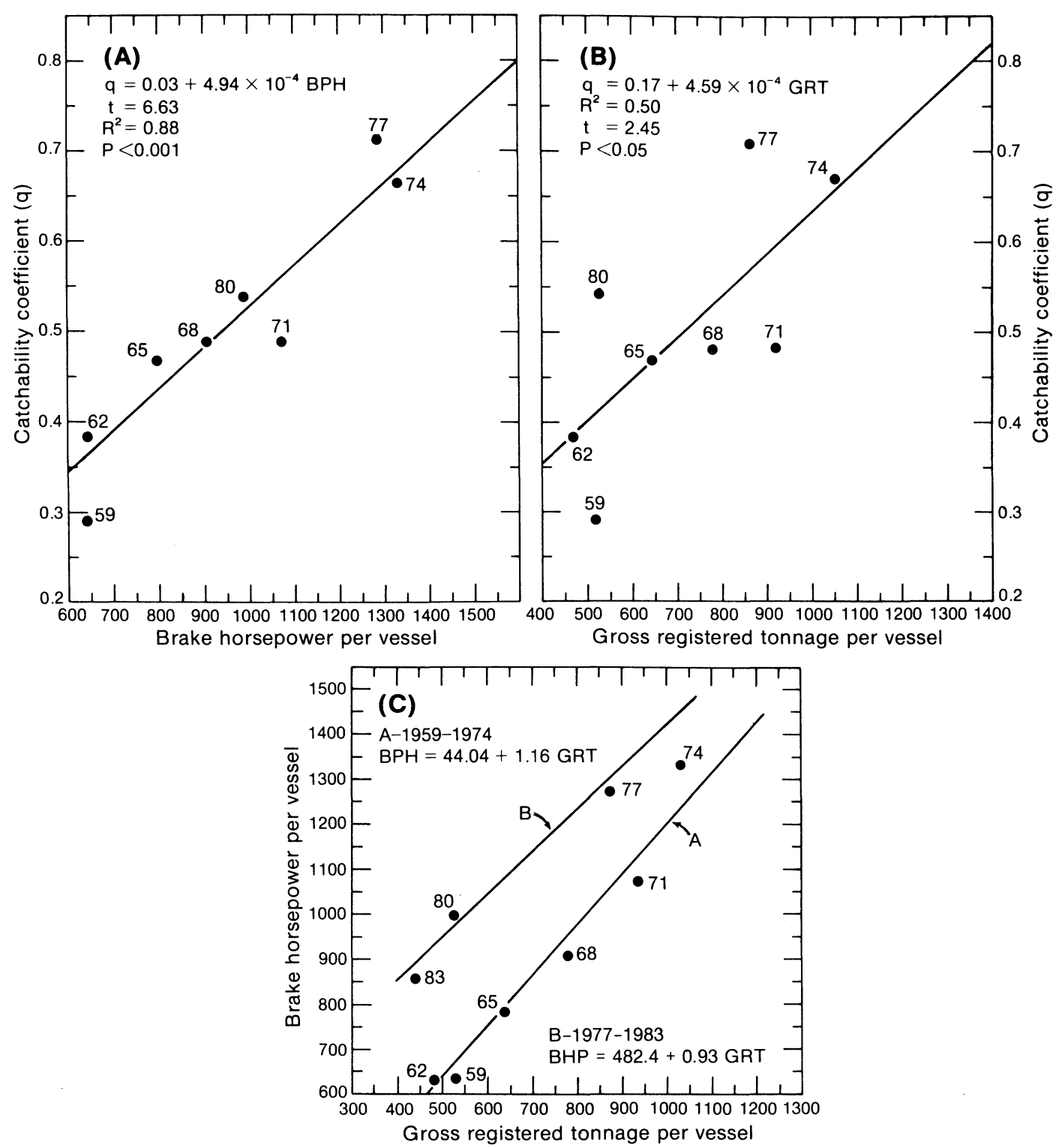

Fig. 4. Regressions of (A) catchability coefficient (q) and brake horsepower per vessel, (B) catchability coefficient (q) and gross registered tonnage per vessel and $(C)$ brake horespower and gross registered tonnage per vessel for some of the major groundfish stocks in the Northwest Atlantic. See text for explanation of method of calculating brake horsepower and gross registered tonnage per vessel and of combining q over stocks.

with the extension of Canadian jurisdiction and the decrease in number of large European trawlers inside the 200-mile zone after 1977. The dual regression lines in Fig. 4C would imply, however, that the countries retained their most powerful vessels in the area after 1977.

Although catch and effort data are not available by BHP categories, because BHP and GRT were shown to be strongly correlated (Fig. 4), catch and effort data from ICNAF/NAFO Statistical Bulletins for the years 1970-84 (ICNAF, 1970-78; NAFO, 1979-84) were used to investigate the trends in relative catch rates and proportion of effort exerted by vessels of various tonnage categories throughout this period.
Catch rates of trawlers $>1800$ GRT were shown to be higher than those for all other tonnage categories in every year, while catch rates for trawlers 901-1800 GRT were generally higher than those for trawlers 501-900 GRT and 151-500 GRT, except for the last 2 years (Fig. 5). Similarly, catch rates for trawlers of 501-900 GRT were higher than those for trawlers of 151-500 GRT. Thus, a unit of effort by larger vessels would remove a larger proportion of the biomass than the same unit by smaller vessels, resulting in a higher $q$ value for larger vessels.

The proportion of the total effort exerted by trawlers $>1800$ GRT increased steadily from 1970 to 1975 and declined rapidly thereafter (Fig. 5). The pro- 


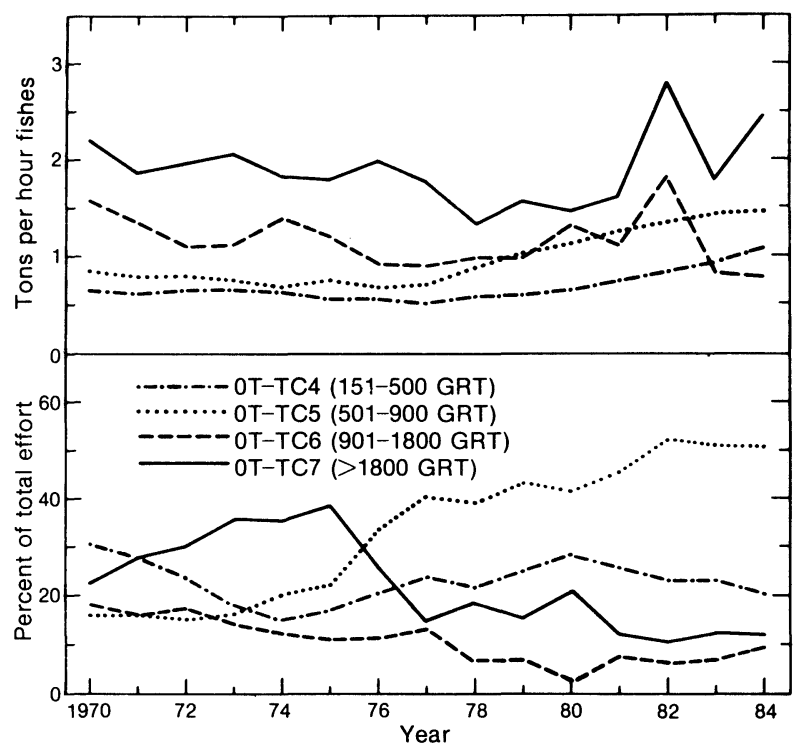

Fig. 5. Trends in catch rates and proportion of effort expended by otter trawlers of various tonnage classes in NAFO Subareas 2-4, during 1970-84.

portion for trawlers of $901-1800$ GRT declined steadily throughout the period, while that for trawlers of 501-900 GRT increased sharply after 1975 and steadily thereafter to 1982. The proportion for trawlers of 151-500 GRT declined until 1974 and then increased to a stable level in 1975-84.

These trends in the proportion of effort exerted by vessels of various tonnage classes coupled with the relative catch rates of vessels in these tonnage categories would be expected to contribute to the increases in q experienced during the 1970 s. Improvements in technology, which likely were greatest in vessel $>1800$ GRT, would have accentuated these increases.

It is therefore concluded from these analyses that the catchability coefficient for the major groundfish stocks in the Northwest Atlantic Ocean changed significantly during the 1970 s and that this change was correlated with changes in vessel technology and the proportion of effort represented by trawlers $>1800$ GRT. Changes in catchability coefficient were not correlated with changes in stock abundance. These changes in catchability coefficinet emphasize the caution necessary in using catch and effort data in groundfish stock assessments. These data are commonly used to tune sequential population analyses by fitting linear regressions to CPUE and exploitable biomass, assuming a constant ratio (catchability coefficient) between these variables over the time series of data used. From these regressions a fishing mortality and hence a stock size in the current year is estimated. If there are trends in catchability coefficient over the time series such as those demonstrated here, stock size estimates for the current year, on which advice on appropriate levels of removals for the following year are based, can be biased.

\section{Acknowledgements}

The author is indebted to J. Rice and W. B. Brodie for reviewing an early draft of the paper and to W. R. Bowering and G. H. Winters for reviewing a revised draft. The author is also indebted to C. A. Bishop, J. Baird, W. B. Brodie, G. Chouinard, J. J. Maguire, R. O'Boyle, R. Mahon and A. Sinclair for permission to use data from NAFO and CAFSAC Research Documents which they authored.

\section{References}

ANTHONY, V. C., and G. WARING. 1980. The assessment and management of the George's Bank herring fishery. ICES Rapp. Proc.-Verb., 177: 72-111.

BAIRD, J. W., and C. A. BISHOP. MS 1985. Assessment of the cod stock in NAFO Divisions $2 \mathrm{~J}+3 \mathrm{KL}$. NAFO SCR Doc., No. 37, Serial No. N987, 38 p.

BISHOP, C. A., and J. W. BAIRD. MS 1985a. Assessment of the cod stock in NAFO Divisions 3NO. NAFO SCR Doc., No. 39, Serial No. N989, 20 p.

MS 1985b. An assessment of the cod stock in Subdivision 3Ps. NAFO SCR Doc., No. 38, Serial No. N988, 25 p.

BRODIE, W. B. MS 1985a. An assessment update of the American plaice stock in NAFO Divisions 3 LNO. NAFO SCR Doc., No. 51, Serial No. N1000, 28 p.

MS 1985b. An assessment of the yellowtail flounder stock in Divisions 3L, 3N, and 3O. NAFO SCR Doc., No. 50, Serial No. N999, 20 p.

BYRNE, C. J., T. R. AZAROVITA, and M. P. SINNENWINE, 1981. Factors affecting variability of research vessel trawl surveys. In: Bottom trawl surveys. W. G. Doubleday and D. Rivard, (ed.), Can. Spec. Pub. Fish. Aquat. Sci. 58: 258273.

CHOUINARD, G. A., and D. CLAY. MS 1985. Assessment of 4TVn (January-April) cod stock for 1985. Can. Atl. Fish. Sci. Adv. Committee Res. Doc., No. 82, 35 p.

CSIRKE, J. 1980. Recruitment in the Peruvian anchovy and its dependence on the adult population. ICES Rapp. Proc.Verb., 177: 307-313.

GAVARIS, S. 1980. Use of a multiplicative model to estimate catch rate and effort from commercial data. Can. J. Fish. Aquat. Sci., 37: 2272-2275.

GAVARIS, S., and A. F. SINCLAIR. MS 1985. Abundance indices of $4 \mathrm{VsW}$ cod, Can. Atl. Fish. Sci. Adv. Committee Res. Doc., No. 39, 18 p.

GULLAND, J. A. 1964. Catch per unit effort as a measure of abundance. ICES Rapp. Proc.-Verb., 155: 8-14.

HOUGHTON, R. G., and S. FLATMAN. 1980. The exploitation pattern, density-dependent catchability, and growth of cod (Gadus morhua) in the west-central North Sea. ICES J. Cons., 39: 271-287.

ICNAF. 1959-77. List of Fishing Vessels. ICNAF List of Vesvels, 1959, 1962, 1965, 1968, 1971, 1974, 1977.

1970-78. Fishery Statistics. ICNAF Stat. Bull., vols. 20-28.

JAKOBSSON, J. 1980. Exploitation of the Icelandic spring and summer-spawning herring in relation to fisheries management, 1947-77. ICES Rapp. Proc.-Verb., 177: 23-42.

MacCALL, A. D. 1976. Density dependence of catchability coefficient in the California pacific sardine, Sardinops 
sagax caerulea, purse seine fishery. Rep. Calif. Ocean. Fish. Invest., 18: 136-148.

MAGUIRE, J. J., D. LEVER, and L. WAITE. MS 1983. Assessment of cod in NAFO Division $4 \mathrm{~T}$ and Subdivision $4 \mathrm{Vn}$ (Jan-Apr) for 1983. Can. Atl. Fish. Sci. Adv. Committee Res. Doc., No. 51, 38 p.

MAHON, R., P. SIMPSON, and D. E. WALDRON. MS 1985. The Eastern Scotian Shelf (4VW) haddock stock and fishery in 1984, with an historical perspective on stock and recruitment back to 1948. Can. Atl. Fish. Sci. Adv. Committee Res. Doc., No. 47, 64 p.

NAFO. 1979-84. Fishery Statistics. NAFO Stat. Bull., vols. 29-34.

1980a. Report of Standing Committee on Fishery Science (STACFIS). NAFO Sci. Coun. Rep. 1979-80: 71-89.

1980b. List of Fishing Vessels. NAFO List of Vesse/s, 1980.

O'BOYLE, R., J. MCMILLAN, and G. WHITE III. MS 1984. The $4 \mathrm{X}$ haddock resource: A problem in supply and demand. Can. Atl. Fish. Sci. Adv. Committee Res. Doc., No. 100, $51 \mathrm{p}$.

PINHORN, A. T. MS 1986. The use of fishing effort as a basis for estimating fishing mortality in $2 \mathrm{~J} 3 \mathrm{KL}$ cod. NAFO SCR Doc., No. 24, Serial No. 1138,4 p.

POPE, J. G. 1972. An investigation of the accuracy of virtual population analysis using cohort analyses. ICNAF Res. Bull., 9: 65-74.

1980. Some consequences for fisheries management of aspects of the behaviour of pelagic fish. ICES Rapp. Proc.-Verb., 177: 466-476.

POPE, J. G., and D. J. GARROD. 1975. Sources of error in catch and effort quota regulations with particular reference to variations in the catchability coefficients. ICNAF Res. Bull., 11: 17-30

RADOVICH, J. 1976. Catch-per-unit-of-effort: fact, fiction, or dogma. Rep. Calif. Ocean. Fish. Invest., 18: 31-33.

1979. Managing pelagic schooling fish species, $p$ 365-376. In: H. Clepper (ed.). Predator-prey systems in fisheries management. Sport Fishing Institute, Washington, DC.

RIVARD, D. 1982. APL program for stock assessment. Can. Tech. Rep. Fish. Aquat. Sci., 1091: 146 p.

SCHAAF, W. E. 1980. An analyses of the dynamic population response of Atlantic menhaden, Brevoortia tyrannus, to an intensive fishery. ICES Rapp. Proc.-Verb., 177: 243-251.

SINCLAIR, A., and S. GAVARIS. MS 1985. Sequential Population Analysis of $4 \mathrm{VsW}$ cod following the 1984 fishery. Can. Atl. Fish. Sci. Adv. Committee Res. Doc., No. 48, 28 p.

ULLTANG, $\emptyset$. 1980. Factors affecting the reaction of pelagic fish stocks to exploitation and requiring a new approach to assessment and management. ICES Rapp. Proc.Verb., 177: 489-504.

WINTERS, G. H., and J. P. WHEELER. 1985. Interaction between stock area, stock abundance, and catchability coefficient. Can. J. Fish. Aquat. Sci., 42: 989-998. 
